\title{
Pd Complexes Based on Phosphine-Linked Cyclophosphazenes: Synthesis, Characterization and Application in Suzuki Coupling Reactions
}

\author{
Vanderlei I. de Paula, Cintia A. Sato and Regina Buffon* \\ Instituto de Química, Universidade Estadual de Campinas, CP 6154, 13083-970 Campinas-SP, Brazil
}

\begin{abstract}
Complexos de paládio foram obtidos pela reação de ciclofosfazenos substituídos com fosfinas, $\left(\mathrm{P}_{3} \mathrm{~N}_{3}\right)\left(\mathrm{O}-\mathrm{C}_{6} \mathrm{H}_{4}-\mathrm{PR}_{2}\right)_{6}$, em que $\mathrm{R}=$ fenil, iso-propil ou cicloexil, com $\mathrm{Pd}_{2}(\mathrm{dba})_{3}$ empregando uma razão molar Pd/ligante de 3/1. Os complexos $\left(\mathrm{P}_{3} \mathrm{~N}_{3}\right)\left(\mathrm{O}-\mathrm{C}_{6} \mathrm{H}_{4}-\mathrm{PR}_{2}\right)_{6} \mathrm{Pd}_{3}(\mathrm{dba})_{\mathrm{x}}$ foram caracterizados por análise elementar, espectrometria de massas, $\mathrm{RMN} \mathrm{de}{ }^{31} \mathrm{P}$ e espectroscopia no infravermelho onde foi sempre observada uma banda característica de $v_{\mathrm{C}=\mathrm{C}}$ de dba coordenado ao paládio. Todos os complexos foram testados em reações de acoplamento de Suzuki entre ácido fenilborônico e haletos de arila. Para complexos em que $\mathrm{R}=$ cicloexil, foram obtidos números de turnover de até 17.500 para o acoplamento entre 2-bromotolueno e ácido clorofenilborônico. O complexo em que $\mathrm{R}=$ fenil foi também imobilizado em matriz de sílica através do processo sol-gel. Experimentos preliminares mostraram que o catalisador imobilizado pode ser usado em pelo menos três reações consecutivas com a mesma atividade catalítica.
\end{abstract}

Palladium complexes were obtained by reaction of phosphine-linked cyclophosphazenes, $\left(\mathrm{P}_{3} \mathrm{~N}_{3}\right)\left(\mathrm{O}-\mathrm{C}_{6} \mathrm{H}_{4}-\mathrm{PR}_{2}\right)_{6}$, where $\mathrm{R}=$ phenyl, $i$-propyl or cyclohexyl, with using a $\mathrm{Pd} /$ ligand molar ratio of $3 / 1$. The $\left(\mathrm{P}_{3} \mathrm{~N}_{3}\right)\left(\mathrm{O}-\mathrm{C}_{6} \mathrm{H}_{4}-\mathrm{PR}_{2}\right)_{6} \mathrm{Pd}_{3}(\mathrm{dba})_{\mathrm{x}}$ complexes were characterized by elemental analyses, mass spectrometry, ${ }^{31} \mathrm{P}$ NMR and FT-IR where a characteristic $v_{\mathrm{C}=\mathrm{C}}$ band of dba coordinated to palladium was always observed. All complexes were tested in Suzuki coupling reactions between phenylboronic acid and aryl halides. Turnover numbers as high as $c a$. 17,500 for the coupling of 2-bromotoluene with chlorophenylboronic acid could be obtained for $\mathrm{R}=$ cyclohexyl. The complex based on $-\mathrm{PPh}_{2}$ was also immobilized in silica matrixes by the sol-gel method. Preliminary experiments showed that the immobilized catalyst could be used in at least three consecutive Suzuki reactions with the same catalytic activity.

Keywords: cyclophosphazenes, palladium complexes, Suzuki coupling reactions, catalyst immobilization

\section{Introduction}

While palladium-catalyzed coupling reactions are powerful tools for the construction of carbon-carbon bonds, ${ }^{1}$ the Suzuki coupling of aryl halides with arylboronic acids has emerged as the most valuable method for the synthesis of biphenyl derivatives. ${ }^{2}$ A combination of palladium with bulky trialkylphosphines, ${ }^{1}$ dialkylbiarylphosphines, ${ }^{3}$ $\mathrm{N}$-heterocyclic carbenes ${ }^{4}$ or other strong $\sigma$-donor ligands ${ }^{5}$ allows the coupling of aryl chlorides under mild conditions, even in water. ${ }^{5,6}$

The use of modified cyclophosphazenes as supporting ligands for transition metals has already been reported: substitution in $\mathrm{P}-\mathrm{Cl}$ bonds has been employed to generate

*e-mail: rbuffon@iqm.unicamp.br nitrogen based ligands (mainly from the pirazoyl type), used to bind copper(II), ${ }^{7}$ and phosphine ligands like 1a (Figure 1), ${ }^{8}$ which has been used to form many complexes with transition metals.

A ligand similar to 1a, bearing five phosphine units, has been employed to bind palladium, affording a complex active in the Heck reaction of aryl iodides. ${ }^{9}$ In this case it was suggested that palladium would bind to two non geminal phosphines, which might allow for a facile de-coordination when compared to a chelating ligand. At the same time, coordination by more than one phosphine would help to prevent leaching of palladium during the catalytic reaction, in particular when the final goal is the heterogenization of the complex, which would allow the recovery of the catalyst and its use in further reactions. 
<smiles>[R]P([R])c1ccc(OP2(Oc3ccc(P([R])P)cc3)=NP(Oc3ccc(P([R])P)cc3)(Oc3ccc(P([R])P)cc3)=NP(Oc3ccc(P([R])P)cc3)(Oc3ccc(P([R])P)cc3)=N2)cc1</smiles>

Figure 1. Cyclophosphazene-based ligands.

Since we have been interested in the immobilization of transition metal complexes by the sol-gel method, ${ }^{10-12}$ with some encouraging results, we thought that type 1 ligands could provide interesting pendant groups to immobilizing palladium complexes on inorganic supports. Therefore, we decided to prepare ligands $\mathbf{1 a - c}$ and the corresponding palladium complexes, which would be characterized and tested in Suzuki coupling reactions.

\section{Experimental}

Materials and methods

All experiments were carried out under argon using standard Schlenk techniques. Cyclophosphazene (Strem) was re-crystallized from hexane. $\mathrm{Pd}_{2} \mathrm{dba}_{3}$ (Strem), boronic acids, hydroxyphenyldiphenylphosphine, chlorophosphines, aryl bromides and chlorides, all purchased from Sigma-Aldrich, were used as received. $\mathrm{K}_{3} \mathrm{PO}_{4}$ (Strem) was dried at $413 \mathrm{~K}$ before use. Solvents were treated according to standard procedures. Silicagel 60 (Merck) was treated under vacuum (ca. $12 \mathrm{mPa})$ at $773 \mathrm{~K}$ for $24 \mathrm{~h}$.

Solution NMR analyses were performed in a Brucker $250 \mathrm{MHz}$ spectrometer, in $\mathrm{CDCl}_{3}$. CP-MAS NMR spectra were recorded with a Bruker Advance II $400 \mathrm{MHz}$ equipment. ESI(+)-MS mass spectra were obtained with a Xevo Q-TOF Waters spectrometer, equipped with a nanoESI ionization source. The samples were dissolved in $\mathrm{H}_{2} \mathrm{O} / \mathrm{MeCN} 1: 1$ containing $0.1 \%$ formic acid, and injected by direct infusion with a flux of $1 \mu \mathrm{L} \mathrm{min}{ }^{-1}$. CHN analyses were carried out with a PerKin Elmer 2400 analyzer. Pd loadings were determined by ICP-OAS using a PerkinElmer Optima 300 DV equipment. Nitrogen adsorption isotherms were determined at $77 \mathrm{~K}$ with a Micromeritics ASAP 2010 automated porosimeter. Catalytic experiments were monitored by gas phase chromatography using an
Agilent 7890 gas chromatograph equipped with an HP 5 capillary column and a flame ionization detector. Halide conversions were determined using calibration curves obtained with standard solutions. GC-MS data were obtained in a GCT Premier Waters equipment using an HP-5 capillary column.

\section{Synthesis of ligands 1a-c}

Hexachlorocyclophosphazene (2.5 g; $7.2 \mathrm{mmol})$, p-bromofenol (7.6 g; $43 \mathrm{mmol})$ and $\mathrm{K}_{2} \mathrm{CO}_{3}(14.3 \mathrm{~g}$; $103 \mathrm{mmol}$ ) were dissolved in $200 \mathrm{~mL}$ acetone and heated under reflux for $1.5 \mathrm{~h}$. The solvent was removed under vacuum and the solid extracted with $\mathrm{CH}_{2} \mathrm{Cl}_{2}$. Yield $7.93 \mathrm{~g}(95 \%)$. Then, $n$-butyl lithium ( $85 \mathrm{mmol}$ ) was added to a cold THF solution containing $1 \mathrm{~g}$ ( $85 \mathrm{mmol})$ of this solid. After $20 \mathrm{~min}$, the desired chlorodialkyl or diarylphosphine (94 mmol) was added and the resulting solution was stirred for $c a .2 .5 \mathrm{~h}$. After reaching room temperature, the ligand was precipitated with ethanol and re-crystallized from THF/acetone.

$\mathrm{N}_{3} \mathrm{P}_{3}\left(\mathrm{O}-\mathrm{C}_{6} \mathrm{H}_{4}-p-\mathrm{PPh}_{2}\right)_{6}(1 \mathrm{a})$

${ }^{1} \mathrm{H}$ NMR: $\delta$ 6.93-6.88 (m, 3H, Ar); $\delta$ 7.28-7.23 (m, $2 \mathrm{H}, \mathrm{Ar}) .{ }^{31} \mathrm{P}\left\{{ }^{1} \mathrm{H}\right\}$ NMR: $\delta-6.8\left(\mathrm{PPh}_{2}\right) ; 8.2\left(\mathrm{~N}_{3} P_{3}\right)$. Yield: $1 \mathrm{~g}(70 \%)$.

$\mathrm{N}_{3} \mathrm{P}_{3}\left(\mathrm{O}-\mathrm{C}_{6} \mathrm{H}_{4}-p-\mathrm{PiPr}_{2}\right)_{6}(\mathbf{1 b})$

${ }^{1} \mathrm{H}$ NMR: $\delta$ 0.8-1.2 (m, 3H, $\left.\mathrm{CH}_{3}\right) ; \delta 2.0(\mathrm{~m}, 1 \mathrm{H}, \mathrm{CH})$; $\delta$ 7.0-6.8 (m, 3H, Ar); $\delta$ 7.28-7.23 (m, 2H, Ar). ${ }^{31} \mathrm{P}\left\{{ }^{1} \mathrm{H}\right\}$ NMR: $\delta 8.6\left(\mathrm{~N}_{3} P_{3}\right) ; 9.9\left(P^{i} \operatorname{Pr}_{2}\right)$. Yield: $0.9 \mathrm{~g}(75 \%)$.

$\mathrm{N}_{3} \mathrm{P}_{3}\left(\mathrm{O}-\mathrm{C}_{6} \mathrm{H}_{4}-p-\mathrm{PCy}\right)_{6}(1 \mathrm{c})$

${ }^{1} \mathrm{H}$ NMR: $\delta$ 0.8-1.3 (m, CH); 1.6-1.8 (m, CH); 6.97 (d, $\left.J_{A B} 8.2 \mathrm{~Hz}, \mathrm{Ar}\right) ; 7.4-7.5(\mathrm{~m}, \mathrm{Ar}) .{ }^{31} \mathrm{P}\left\{{ }^{1} \mathrm{H}\right\}$ NMR: $\delta 1.8$ $\left(P \mathrm{Cy}_{2}\right) ; 8.1\left(\mathrm{~N}_{3} P_{3}\right)$. Yield: $1.2 \mathrm{~g}(75 \%)$.

\section{Synthesis of palladium complexes}

The appropriate amount $(1.15 \mathrm{mmol})$ of the desired ligand was dissolved in $10 \mathrm{~mL}$ THF followed by addition of $\mathrm{Pd}_{2} \mathrm{dba}_{3}(1.58 \mathrm{~g} ; 1.73 \mathrm{mmol})$. After $1 \mathrm{~h}$ under stirring, the solvent was removed under vacuum. After addition of $10 \mathrm{~mL}$ benzene, the liquid phase was filtered off and dried under vacuum. The resulting solid was washed with ether/hexane $(50 \% \mathrm{v} / \mathrm{v})$ in order to remove excess of dba. After filtering off, the solution was dried and the solid washed with hexane.

$\mathrm{N}_{3} \mathrm{P}_{3}\left(\mathrm{O}-\mathrm{C}_{6} \mathrm{H}_{4}-p-\mathrm{PPh}_{2}\right)_{6} / \mathrm{Pd}_{3}(\mathrm{dba})\left(\mathbf{1 a P d}_{3}(\mathbf{d b a})\right)$

Red purple solid; yield: $3 \mathrm{~g}(95 \%)$; ${ }^{1} \mathrm{H}$ NMR: $\delta$ 7.4-7.6 $(\mathrm{m}, 3 \mathrm{H}, \mathrm{Ar}) ; \delta 8.1(\mathrm{~m}, 2 \mathrm{H}, \mathrm{Ar}) .{ }^{31} \mathrm{P}\left\{{ }^{1} \mathrm{H}\right\} \mathrm{NMR}\left(\mathrm{D}_{2} \mathrm{O} /\right.$ $\left.\mathrm{H}_{3} \mathrm{PO}_{4}\right): \delta 7.4\left(\mathrm{~s}, \mathrm{~N}_{3} P_{3}\right) ; 29.4\left(\mathrm{~s}, P \mathrm{Ph}_{2}\right)$. FT-IR $v_{\text {max }} / \mathrm{cm}^{-1}$ : 
3058; 1626; 1586; 1489; 1433; 1394; 1204; 1184; 956; 887; 553. Elemental analyses: Found C 63.1\%; H 3.7\%; N 1.7 $\%$. Calculated for $\mathbf{1 a P d}_{3}(\mathbf{d b a})$ : C 63.8\%; H 4.2\%; N $1.8 \%$.

$\mathrm{N}_{3} \mathrm{P}_{3}\left(\mathrm{O}-\mathrm{C}_{6} \mathrm{H}_{4}-p-\mathrm{PiPr}_{2}\right)_{6} / \mathrm{Pd}_{3}(\mathrm{dba})_{3}\left(\mathbf{1 b P d}_{3}(\mathbf{d b a})_{3}\right)$

Green solid. Yield: 1.9g (68.9\%). ${ }^{1} \mathrm{H}$ NMR: $\delta 1.0$ (m, 12H, $\left.\mathrm{CH}_{3}\right) ; 1.5$ (m, 2H, CH); 6.95 (s, Ar); 7.01 (s, Ar); 7.14 (m, Ar); 7.32 (m, dba); 7.86 (s, dba); 7.93 (s, dba). ${ }^{31} \mathrm{P}\left\{{ }^{1} \mathrm{H}\right\}$ NMR $\left(\mathrm{D}_{2} \mathrm{O} / \mathrm{H}_{3} \mathrm{PO}_{4}\right): \delta 9.0\left(\mathrm{~s}, \mathrm{~N}_{3} P_{3}\right) ; 49.5\left(\mathrm{~s}, P^{i} \mathrm{Pr}_{2}\right)$. FT-IR $V_{\text {max }} / \mathrm{cm}^{-1}: 3058 ; 2964 ; 2929 ; 2871 ; 1648 ; 1618 ; 1590 ; 1538$; $1206 ; 1165 ; 952 ; 884 ; 553$. Elemental analyses: Found C $60.5 \%$; H $5.9 \%$; N $1.7 \%$. Calculated for $\mathbf{1 b P d}_{3}(\mathbf{d b a})_{3}$ : C $61.2 \%$; H $5.9 \%$; N $1.7 \%$.

\section{$\mathrm{N}_{3} \mathrm{P}_{3}\left(\mathrm{O}-\mathrm{C}_{6} \mathrm{H}_{4}-p-\mathrm{PCy}_{2}\right)_{6} / \mathrm{Pd}_{3}(\mathrm{dba})\left(\mathbf{1} \mathrm{cPd}_{3}(\mathrm{dba})\right)$}

Ochre yellow solid; yield: $2.4 \mathrm{~g}(73.5 \%) .{ }^{1} \mathrm{H}$ NMR: $\delta 0.9(\mathrm{~m}, \mathrm{CH}) ; 1.3\left(\mathrm{~m}, \mathrm{CH}_{2}\right) ; 1.6(\mathrm{~m}, \mathrm{CH}) ; 7.01$ (s, Ar); 7.15 (s, Ar); 7.2 (m, Ar); 7.4 (m, dba); 7.60 (m, dba); 7.65 (m, Ar); 7.75 (m, Ar); 7.8 (m, dba); 7.9 (m, dba). ${ }^{31} \mathrm{P}\left\{{ }^{1} \mathrm{H}\right\}$ NMR $\left(\mathrm{D}_{2} \mathrm{O} / \mathrm{H}_{3} \mathrm{PO}_{4}\right): \delta 7.3\left(\mathrm{~s}, \mathrm{~N}_{3} P_{3}\right) ; 50.6\left(\mathrm{~s}, P C y_{2}\right)$.

FT-IR $v_{\text {max }} / \mathrm{cm}^{-1}$ : 2928; 2851; 1650; 1622; 1493; 1208; 1186. Elemental analyses: Found C $60.2 \%$; H 5.4\%; N 1.7\%. Calculated for $\mathbf{1 c P d}_{3}(\mathbf{d b a}): \mathrm{C} 61.9 \% ; \mathrm{H} 7 \% ; \mathrm{N} 1.7 \%$.

\section{General procedure for immobilization by the sol-gel method}

Tetramethoxysilane $(8.2 \mathrm{mg} ; 0.054 \mathrm{mmol})$ and $\mathrm{HCl}$ (3.3 mL; $\mathrm{pH} 2$ ) were added to a Schlenk flask containing a solution of $\mathbf{1 a P d}_{3}(\mathbf{d b a})(56.5 \mathrm{mg} ; 0.027 \mathrm{mmol})$ in THF (35 mL). After 15 min under stirring, a concentrated aqueous solution of $\mathrm{Cs}_{2} \mathrm{CO}_{3}(c a .2 \mathrm{~mL})$ was added. The mixture was allowed to stand for 2 days and the resulting solid was dried under vacuum for $10 \mathrm{~h}$; then washed with THF in a Soxhlet. After drying again under vacuum, a brown solid containing $0.06 \mathrm{wt}$ \% of palladium was obtained.

Synthesis of $\mathrm{N}_{3} \mathrm{P}_{3}\left(\mathrm{O}-\mathrm{C}_{6} \mathrm{H}_{4}-p-\mathrm{P}\left(\mathrm{C}_{6} \mathrm{H}_{5}\right)_{2}\right)_{5}\left(\mathrm{O}-\mathrm{C}_{6} \mathrm{H}_{4}-p-\mathrm{C}_{6} \mathrm{H}_{4}-p-\right.$ $\mathrm{O}\left(\mathrm{CH}_{2}\right)_{3} \mathrm{Si}\left(\mathrm{OCH}_{3}\right)_{3}, 1 \mathrm{a}^{\prime}$

The synthesis was carried out in four steps, using Schlenk techniques: (i) Synthesis of $\mathrm{N}_{3} \mathrm{P}_{3} \mathrm{Cl}_{5}(\mathrm{O}-$ $\left.\mathrm{C}_{6} \mathrm{H}_{4}-p-\mathrm{C}_{6} \mathrm{H}_{4}-p-\mathrm{OCH}_{3}\right)$, A: A THF $(9 \mathrm{~mL})$ solution of 4-hidroxy-4'-metoxybiphenyl (90 mg; $0.4 \mathrm{mmol}$ ) and triethylamine ( $41 \mathrm{mg} ; 0.4 \mathrm{mmol}$ ) was added drop by drop to a THF ( $8 \mathrm{~mL}$ ) solution of cyclophosphazene $(139 \mathrm{mg}$; $0.4 \mathrm{mmol}$ ). After $6 \mathrm{~h}$ stirring at room temperature, the solution was filtered off and the slurry was dried under vacuum. After extraction with hexane and vacuum drying, a yellow solid was obtained. (ii) Synthesis of $\mathrm{N}_{3} \mathrm{P}_{3}\left(\mathrm{O}-\mathrm{C}_{6} \mathrm{H}_{4}-p-\mathrm{P}\left(\mathrm{C}_{6} \mathrm{H}_{5}\right)_{2}\right)_{5}\left(\mathrm{O}-\mathrm{C}_{6} \mathrm{H}_{4}-p-\mathrm{C}_{6} \mathrm{H}_{4}-p-\mathrm{OCH}_{3}\right)$, B: A mixture of $\mathbf{A}(51.1 \mathrm{mg} ; 0.1 \mathrm{mmol})$, (4-hidroxyphenyl) diphenylphosphine $(139.1 \mathrm{mg} ; 0.5 \mathrm{mmol})$ and $\mathrm{Cs}_{2} \mathrm{CO}_{3}$
(194 mg; $0.6 \mathrm{mmol})$ in acetone $(15 \mathrm{~mL})$ was stirred for $2 \mathrm{~h}$, under reflux. Then, the solvent was filtered off and a brownish solid was obtained after drying under vacuum. (iii) Synthesis of $\mathrm{N}_{3} \mathrm{P}_{3}\left(\mathrm{O}-\mathrm{C}_{6} \mathrm{H}_{4}-p-\mathrm{P}\left(\mathrm{C}_{6} \mathrm{H}_{5}\right)_{2}\right)_{5}\left(\mathrm{O}-\mathrm{C}_{6} \mathrm{H}_{4}-p\right.$ $\left.\mathrm{C}_{6} \mathrm{H}_{4}-p-\mathrm{OH}\right), \mathbf{C}: \mathrm{BBr}_{3}-\mathrm{Me}_{2} \mathrm{~S}(156.3 \mathrm{mg} ; 0.5 \mathrm{mmol})$ was added to a 1,2-dichloroethane $(15 \mathrm{~mL})$ solution of $\mathbf{B}$ (192.3 mg; $0.1 \mathrm{mmol})$. The system was heated under reflux and left under stirring for $48 \mathrm{~h}$. After neutralization with $\mathrm{NaHCO}_{3}$ and work-up, a brown solid was obtained. (iv) Synthesis of $\mathrm{N}_{3} \mathrm{P}_{3}\left(\mathrm{O}-\mathrm{C}_{6} \mathrm{H}_{4}-p-\mathrm{P}\left(\mathrm{C}_{6} \mathrm{H}_{5}\right)_{2}\right)_{5}\left(\mathrm{O}-\mathrm{C}_{6} \mathrm{H}_{4}-p-\mathrm{C}_{6} \mathrm{H}_{4}-p-\right.$ $\left.\mathrm{O}\left(\mathrm{CH}_{2}\right)_{3} \mathrm{Si}\left(\mathrm{OCH}_{3}\right)_{3}\right)$, 1a': A mixture of $\mathbf{C}($ ca. $0.1 \mathrm{mmol})$, KI (1.8 mg; $0.011 \mathrm{mmol}), 2$-aminopyridine $(0.1 \mathrm{mg}$; $0.0011 \mathrm{mmol})$, 4-bromoanisol (0.21 mg; $0.0011 \mathrm{mmol})$, (3-chloropropyl)trimethoxysilane (21.9 mg; $0.11 \mathrm{mmol})$ in DMF (3 mL) was stirred at $145^{\circ} \mathrm{C}$ for $24 \mathrm{~h}$. After work-up, a brown waxy solid was recovered.

\section{Immobilization on silica}

Ligand 1a' was allowed to react with $\mathrm{Pd}_{2} \mathrm{dba}_{3}$ (ca. $1 \mathrm{mmol}$ ) in DMF (20 mL). Previous treated silica (1 g) was then added and the mixture was stirred at $423 \mathrm{~K}$ for $16 \mathrm{~h}$. The liquid phase was filtered off and the resulting solid was washed with THF in a Soxhlet. Upon drying under vacuum, a yellow solid was obtained. CP-MAS NMR: ${ }^{31} \mathrm{P}$ : $\delta 22(\mathrm{P}-\mathrm{Pd}) .{ }^{13} \mathrm{C}: \delta 0(\mathrm{C}-\mathrm{Si}), 10\left(\mathrm{O}-\mathrm{CH}_{3}\right), 15-30\left(\mathrm{CH}_{2}\right)$, 110-125 (biphenyl), 125-140 (Ph). Pd loading: 0.12 wt.\%.

\section{General procedures for Suzuki reactions}

\section{Method A}

The reactions were carried in a $10 \mathrm{~mL}$ reaction flask, adapted to a condenser. Phenylboronic acid $(0.8 \mathrm{mmol})$, bromobenzene ( $80 \mathrm{mg} ; 0.5 \mathrm{mmol}), \mathrm{K}_{3} \mathrm{PO}_{4}(212 \mathrm{mg}$; $1 \mathrm{mmol})$ and a solution of the catalyst in THF $(4 \mathrm{~mL}$; $1.0 \mathrm{~mol} \% \mathrm{Pd}$ ) were stirred at $343 \mathrm{~K}$ for $24 \mathrm{~h}$.

\section{Method B}

The reactions were carried out in a sealed Schlenk. In a typical experiment, $100 \mathrm{mg}(0.46 \mathrm{mmol}) \mathrm{K}_{3} \mathrm{PO}_{4}, 42.8 \mathrm{mg}$ $(0.35 \mathrm{mmol})$ phenylboronic acid, $36.8 \mathrm{mg}(0.23 \mathrm{mmol})$ bromobenzene, $\left(1.15 \times 10^{-3} \mathrm{mmol}\right) \mathrm{Pd}, 0.5 \mathrm{~mL}$ THF, $1.5 \mathrm{~mL}$ toluene and $100 \mu \mathrm{L}$ deca-hydronaftalene (internal standard) were heated at $383 \mathrm{~K}$ for up to $24 \mathrm{~h}$ and analyzed by GC.

The final mixture was extracted with ethyl ether and the organic phase was washed with an aqueous solution of $\mathrm{NaOH} 1 \mathrm{~mol} \mathrm{~L}^{-1}$ and analyzed by ${ }^{1} \mathrm{H}(250 \mathrm{MHz})$ and ${ }^{13} \mathrm{C}\left\{{ }^{1} \mathrm{H}\right\}(62.9 \mathrm{MHz}) \mathrm{NMR}$, in $\mathrm{CDCl}_{3}$ and/or by GC/MS. Although all products were isolated, yields were calculated as a function of halide consumption. All catalytic experiments were carried out in duplicate. 


\section{Procedure for recycling experiments}

The reaction was carried out in the same way as for the homogeneous system. After the reaction, the liquid phase was filtered off and the solid was washed in a Soxhlet with THF, deionized water and THF, sequentially. After drying under vacuum, the Pd loading was determined by ICP-OAS and the catalyst used in another run.

\section{Results and Discussion}

In order to determine the viability of using such complexes as catalysts in Suzuki coupling reactions, preliminary experiments were carried out with ligand 1a prepared by reacting hexachlorocyclophosphazene with $p$-hydroxyphenyldiphenylphosphine. ${ }^{13}$ In further experiments, ligands 1a-c were synthesized from hexachlorocyclophosphazene via nucleophilic substitution with $p$-bromophenol, followed by lithiation of the aromatic ring and reaction with chlorodiphenylphosphine (a) or chlorodialkylphosphines, where alkyl $=i$-propyl $(\mathbf{b})$ or cyclohexyl (c), in a procedure adapted from the literature. ${ }^{8}$ Ligands $\mathbf{1 b}$ and $\mathbf{1 c}$ are described for the first time. All syntheses were straightforward and almost quantitative. The ${ }^{31} \mathrm{P}$ NMR spectra of all ligands showed a resonance assigned to phosphorous in the ring and another one for the corresponding phosphine groups (Table 1).

\section{Determination of the best $\mathrm{Pd} /$ /ligand 1a molar ratio}

It is known that 1a may act as a mono- or bidentate ligand for low oxidation transition metal complexes. ${ }^{8}$ Since the only $\mathrm{Pd}$ complex of this type of ligand already reported contained one palladium per unit of cyclophosphazene, ${ }^{9}$ we started our work determining the ligand/Pd molar ratio that would provide the best catalyst for Suzuki reactions. Therefore, ligand 1 a was reacted with $\operatorname{Pd}_{2}(\mathrm{dba})_{3}$ using palladium/ligand stoichiometries varying from 1 to 3 and the resulting complexes (without purification) were tested in the Suzuki reaction between bromobenzene and phenylboronic acid, Scheme $1(\operatorname{method} A)$.

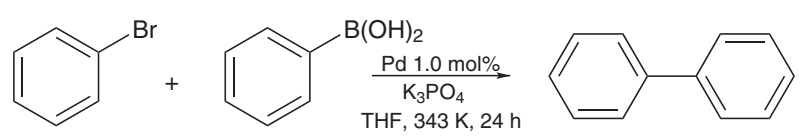

Scheme 1. Suzuki reaction (method A).

For $\mathrm{Pd} / \mathbf{1 a}$ stoichiometries (n) of 1 and 2, the reaction yields were low (TON $=14$ and 36 , respectively) while a better yield was obtained for $n=3(\mathrm{TON}=123)$. Therefore, $\mathrm{n}=3$ was chosen for further experiments.

Syntheses and characterization of $\mathbf{1 a P d}_{3}(\mathbf{d b a}), \mathbf{1 b P d}_{3}(\mathbf{d b a})_{3}$ and $\mathbf{1} \mathbf{c P d} \mathbf{P}_{3}(\mathbf{d b a})$ complexes

Using a $\mathrm{Pd} /$ ligand ratio of $3 / 1$, ligands 1 a-c reacted promptly with $\mathrm{Pd}_{2}(\mathrm{dba})_{3}$ as a color change in the reaction solution was immediately observed. The complexes were purified by precipitation with hexane at low temperature to remove the excess of dba. Although all Pd complexes presented dba ligands, as evidenced by elemental analyses, ${ }^{1} \mathrm{H}$ NMR and infrared spectroscopy (where a characteristic $\mathrm{v}_{\mathrm{C}=\mathrm{C}}$ band of dba coordinated to palladium was observed in each case, Table 1), Pd/dba stoichiometries varied in each synthesis, being lower than (or close to) one. In

Table 1. Selected spectroscopic data for ligands and corresponding Pd complexes

\begin{tabular}{|c|c|c|c|}
\hline Ligands and Complexes & ${ }^{31} \mathrm{P} \mathrm{NMR} / \delta$ & $\operatorname{MS}(m / z)$ & $\begin{array}{l}\text { FT-IR/cm }{ }^{-1} \\
\mathrm{dba}\left(v_{\mathrm{c}=\mathrm{c}}\right)\end{array}$ \\
\hline$\left[\mathrm{Pd}\left\{\mathrm{P}\left({ }^{i} \mathrm{Pr}\right)_{3}\right\}_{2}\right]^{14}$ & 49.3 & & \\
\hline$\left[\mathrm{Pd}\left(\mathrm{PCy}_{3}\right)_{2}\right]^{15}$ & 39.7 & & \\
\hline $\mathrm{PCy}_{3}{ }^{15}$ & 10.9 & & \\
\hline $1 \mathbf{a}^{\mathrm{a}}$ & $8.2\left(\mathrm{~N}_{3} \mathrm{P}_{3}\right) ;-6.8\left(\mathrm{PPh}_{2}\right)$ & $1799.2[\mathrm{M}+\mathrm{H}]^{+} ; 900.2[\mathrm{M}+2 \mathrm{H}]^{2+}$ & \\
\hline $1 \mathbf{b}$ & $8.6\left(\mathrm{~N}_{3} \mathrm{P}_{3}\right) ; 9.9\left(\mathrm{P}^{i} \mathrm{Pr}_{2}\right)$ & $1390.5[\mathrm{M}+\mathrm{H}]^{+} ; 464.1[\mathrm{M}+3 \mathrm{H}]^{3+}$ & \\
\hline $1 \mathrm{c}$ & $8.1\left(\mathrm{~N}_{3} \mathrm{P}_{3}\right) ; 1.8\left(\mathrm{PCy}_{2}\right)$ & $936.5[\mathrm{M}+2 \mathrm{H}]^{2+} ; 624.6[\mathrm{M}+3 \mathrm{H}]^{3+}$ & \\
\hline $1 \mathrm{aPd}_{3}(\mathrm{dba})$ & $7.4\left(\mathrm{P}_{3} \mathrm{~N}_{3}\right) ; 29.4\left(\mathrm{PPh}_{2}\right)$ & $\begin{array}{c}1117.7\left[\mathrm{M}+2 \mathrm{H}^{+}\right]^{2+} \\
\left(3 \mathrm{Pd}+2 \mathrm{H}_{2} \mathrm{O}+2 \mathrm{NCCH}_{3}\right)\end{array}$ & 1626 \\
\hline $1 \mathrm{bPd}_{3}(\mathrm{dba})_{3}$ & $9.0\left(\mathrm{P}_{3} \mathrm{~N}_{3}\right) ; 49.5\left(\mathrm{P}^{i} \mathrm{Pr}_{2}\right)$ & $\begin{array}{c}1153\left[\mathrm{M}+2 \mathrm{Na}^{+}\right]^{2+} \\
\left(3 \mathrm{Pd}+2 \mathrm{dba}+2 \mathrm{NCCH}_{3}\right)\end{array}$ & 1618 \\
\hline $\mathbf{1 c P d}_{3}(\mathrm{dba})$ & $7.3\left(\mathrm{P}_{3} \mathrm{~N}_{3}\right) ; 50.6\left(\mathrm{PCy}_{2}\right)$ & $\begin{array}{c}1330\left[\mathrm{M}+2 \mathrm{H}^{+}\right]^{2+} \\
(3 \mathrm{Pd}+2 \mathrm{dba})\end{array}$ & 1622 \\
\hline
\end{tabular}

${ }^{a}$ In ref. 8: $\delta 8$ and -7 ; in ref. 13: $\delta 8.8$ and -6.4 . 
fact, ${ }^{1} \mathrm{H}$ NMR suggests the presence of coordinated and uncoordinated dba. Further attempts to remove all excess of dba always led to decomposition and/or precipitation of an untreatable solid. ${ }^{31} \mathrm{P}\left\{{ }^{1} \mathrm{H}\right\}$ NMR spectra of the complexes show only two singlets, one for the cyclophosphazene unit $\left(\mathrm{N}_{3} \mathrm{P}_{3}\right)$ and other for the phosphine groups $(\mathrm{P})$, strongly suggesting a ligand/Pd stoichiometry of $1 / 3$, with each $\mathrm{Pd}$ coordinated to two phosphines (upon complexation, a shift of the phosphorus resonance to low field was observed in each case, but less pronounced for $\mathbf{1 c P d}_{\mathbf{3}}(\mathbf{d b a})$, Table 1). Mass spectrometry supports the proposed ligand/palladium stoichiometry as a fragmentation ion corresponding to 3Pd was always present (Table 1). The observation of a singlet in the ${ }^{31} \mathrm{P}$ NMR spectra for the phosphine groups in all complexes strongly suggests that these groups are trans to each other, a situation that might be favored by non geminal phosphine ligands. However, without X-ray diffraction studies, we cannot decide whether the phosphine groups are geminal or not.

\section{Catalytic activity}

Since all complexes are highly soluble in THF, this solvent was chosen for the first experiments. The complexes were tested in coupling reactions between phenylboronic acid and several deactivated and activated, hindered or not, arylbromides, as shown in Table 2.

Within the experimental error, $\mathrm{Pd}_{2} \mathrm{dba}_{3} / \mathrm{PPh}_{3}$ and $\mathbf{1 a P d}_{\mathbf{3}}(\mathbf{d b a})$ led to the same TON in the coupling with bromobenzene, strongly suggesting that, at least in this case, the cyclophosphazene backbone does not hamper the decoordination of a phosphine. Reactions were quite selective to the desired products even when the arylbromide was substituted with hydroxi or amino groups (Table 2, entries 18,19 and 24, respectively). Nevertheless, small amounts (not quantified) of biphenyl (probably a homocoupling product of the phenylboronic acid) were always observed. The dicylohexylphosphine derivative $\left(\mathbf{1} \mathbf{c P d} \mathbf{d}_{\mathbf{3}}(\mathbf{d b a})\right)$ gave the best results, showing activity even towards orto-substituted arylchlorides (Table 2, entries 8 and 13). Therefore, the effect of the reaction temperature was studied with this complex, which showed no activity at ambient conditions.

As it can be seen in Table 3, for a deactivated, non hindered arylbromide, increasing the temperature from $353 \mathrm{~K}$ to $383 \mathrm{~K}$ had no effect in turnover numbers; however, for the chloride analogue the TON increased by more than $50 \%$. Toluene appeared to have a slight beneficial effect on catalytic activity (Table 3, entries 5 and 6). However, since all complexes are sparingly soluble in toluene at room temperature, they were first dissolved in THF in such a
Table 2. Suzuki reactions of phenylboronic acid with phenyl halides $(\mathrm{R}-\mathrm{X})$ catalyzed by $\mathbf{1 b P d}_{3}(\mathbf{d b a})_{3}, \mathbf{1}(\mathbf{a}, \mathbf{c}) \mathbf{P d}_{3}(\mathbf{d b a})^{\mathrm{a}}$

\begin{tabular}{|c|c|c|c|c|}
\hline entry & ligand & $\mathrm{R}-\mathrm{X}$ & yield / \% & $\mathrm{TON}^{\mathrm{d}}$ \\
\hline $\begin{array}{l}1 \\
2\end{array}$ & $\begin{array}{c}\mathrm{PPh}_{3}{ }^{\mathrm{b}} \\
\mathbf{1 a}\end{array}$ & & $\begin{array}{l}78.5 \\
77.7\end{array}$ & $\begin{array}{l}157 \\
155\end{array}$ \\
\hline $\begin{array}{l}3 \\
4 \\
5\end{array}$ & $\begin{array}{l}1 \mathrm{a} \\
1 \mathrm{~b} \\
1 \mathrm{c}\end{array}$ & & $\begin{array}{c}53.4 \\
79 \\
77.3\end{array}$ & $\begin{array}{l}107 \\
159 \\
155\end{array}$ \\
\hline $\begin{array}{l}6 \\
7 \\
8\end{array}$ & $\begin{array}{l}1 \mathrm{a} \\
1 \mathrm{~b} \\
1 \mathrm{c}\end{array}$ & & $\begin{array}{c}1 \\
23.9 \\
32.4\end{array}$ & $\begin{array}{c}2 \\
48 \\
65\end{array}$ \\
\hline $\begin{array}{c}9 \\
10\end{array}$ & $\begin{array}{l}1 \mathrm{a} \\
1 \mathrm{c}\end{array}$ & & $\begin{array}{c}0.9 \\
12.2\end{array}$ & $\begin{array}{c}2 \\
24\end{array}$ \\
\hline $\begin{array}{l}11 \\
12 \\
13\end{array}$ & $\begin{array}{l}1 \mathrm{a} \\
1 \mathrm{~b} \\
1 \mathrm{c}\end{array}$ & . & $\begin{array}{c}3.8 \\
17.4 \\
36.8\end{array}$ & $\begin{array}{c}8 \\
35 \\
74\end{array}$ \\
\hline $\begin{array}{l}14 \\
15\end{array}$ & $\begin{array}{l}1 \mathrm{a} \\
1 \mathrm{c}\end{array}$ & & $\begin{array}{l}23.4 \\
85.4\end{array}$ & $\begin{array}{c}47 \\
171\end{array}$ \\
\hline $\begin{array}{l}16 \\
17\end{array}$ & $\begin{array}{l}1 \mathrm{a} \\
1 \mathrm{c}\end{array}$ & & $\begin{array}{l}47.7 \\
85.6\end{array}$ & $\begin{array}{c}95 \\
171\end{array}$ \\
\hline $\begin{array}{l}18 \\
19\end{array}$ & $\begin{array}{l}1 \mathrm{~b} \\
1 \mathrm{c}\end{array}$ & & $\begin{array}{l}72.8 \\
71.7\end{array}$ & $\begin{array}{l}146 \\
143\end{array}$ \\
\hline $\begin{array}{l}20 \\
21\end{array}$ & $\begin{array}{l}1 \mathrm{~b} \\
1 \mathrm{c}\end{array}$ & & $\begin{array}{c}2.9 \\
10.5\end{array}$ & $\begin{array}{c}6 \\
21\end{array}$ \\
\hline 22 & $1 \mathrm{c}$ & & 99 & 198 \\
\hline 23 & $1 \mathrm{c}$ & & 96.1 & 192 \\
\hline 24 & $1 \mathrm{c}$ & & 50.7 & 101 \\
\hline
\end{tabular}

a $[\mathrm{RX}] /\left[(\mathrm{OH})_{2} \mathrm{BPh}\right] /\left[\mathrm{K}_{3} \mathrm{PO}_{4}\right]=1.0 / 1.5 / 5 ;[\mathrm{Pd}] /[\mathrm{RX}]=1 / 200 ; \mathrm{THF} ; 353 \mathrm{~K} ;$

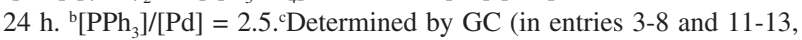
only the monoarylated products were observed); ${ }^{\mathrm{d}} \mathrm{mol}$ of converted RX per mol of Pd. 
Table 3. Effects of temperature and solvent in Suzuki reactions of phenylboronic acid with aryl halides catalyzed by $\mathbf{1} \mathbf{c P d}_{3}(\mathbf{d b a})^{\mathrm{a}}$

\begin{tabular}{|c|c|c|c|c|}
\hline entry & $\begin{array}{c}\text { Temperature / K } \\
\text { (solvent) }\end{array}$ & $\mathrm{R}-\mathrm{X}$ & yield / \% & TON \\
\hline 1 & 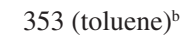 & & 85.9 & 172 \\
\hline 2 & 383 (toluene) $^{\mathrm{b}}$ & & 86.3 & 173 \\
\hline 3 & 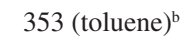 & & 25.2 & 50 \\
\hline 4 & 383 (toluene) $^{\mathrm{b}}$ & & 39.2 & 78 \\
\hline 5 & 353 (toluene) $^{\mathrm{b}}$ & & 81.6 & 163 \\
\hline 6 & 353 (THF) & & 77.3 & 155 \\
\hline
\end{tabular}

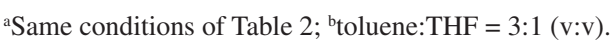

way that the toluene/THF final ratio would be $3 / 1 \mathrm{v} / \mathrm{v}$. In these conditions, the catalytic activity of the complexes in the coupling between phenylboronic acid and 1-bromo2-chlorobenzene was studied as a function of time. From Figure 2, initial turnover frequencies (at 20\% conversion) for $\mathbf{1 b P d}_{3}(\mathbf{d b a})_{3}$ and $\mathbf{1} \mathbf{c P d} \mathbf{d}_{\mathbf{3}}(\mathbf{d b a})$ could be estimated as $600 \mathrm{mmol} \mathrm{h}^{-1}$. In all cases equilibrium was reached in $c a$. $2 \mathrm{~h}$ at $383 \mathrm{~K}$. Similar profiles were obtained when the halide was bromobenzene. These optimized conditions were used in further experiments.

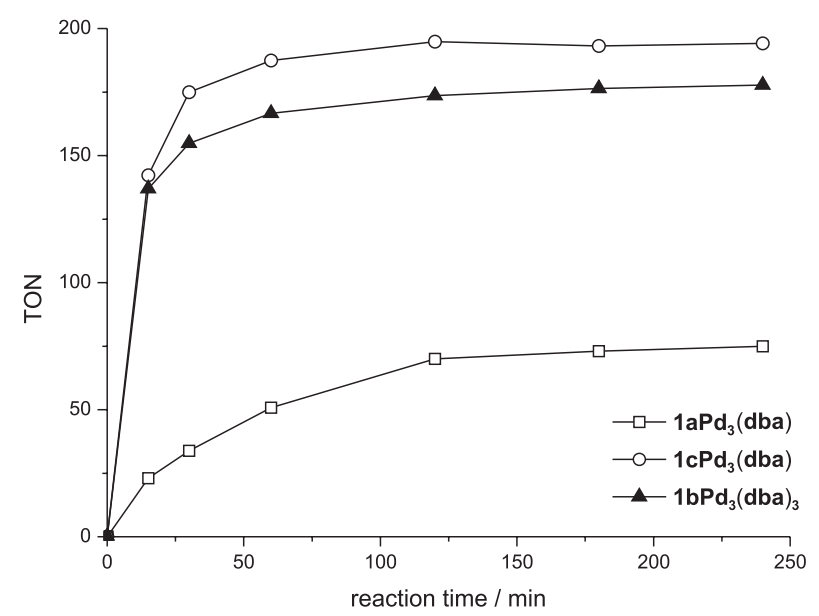

Figure 2. Catalytic activity as a function of time for the coupling of phenylboronic acid with 1-bromo-2-chlorobenzene. $[\mathrm{Pd}] /[\mathrm{RX}]=1 / 200$; $[\mathrm{RX}] /\left[(\mathrm{OH})_{2} \mathrm{BPh}\right] /\left[\mathrm{K}_{3} \mathrm{PO}_{4}\right]=1.0 / 1.5 / 5$; toluene; $383 \mathrm{~K}$.

Table 4 shows that $\mathbf{1} \mathbf{c P d} \mathbf{d}_{\mathbf{3}}(\mathbf{d b a})$ is able to catalyze the coupling of 2-bromotoluene with ortosubstituted phenylboronic acids: the yield obtained for 2-methoxiphenylboronic acid was lower than that afforded by the corresponding 4-methoxi analogue, but even for the hindered substrate in entry 4 a good conversion was observed, suggesting that the ligand backbone does not hamper the access to the active sites.

The catalyst $\mathbf{1} \mathbf{c P d} \mathbf{P d}_{\mathbf{3}}(\mathbf{d b a})$ was also tested using low catalyst loadings ([Pd]/[bromotoluene] ca.1/28,000), as shown in Table 5. A TON of $c a .17,500$ was obtained for the

Table 4. Effects of substitution in the phenylboronic acid in reactions catalyzed by $1 \mathbf{c P d}(\mathbf{d b a})^{\mathrm{a}}$

entry halide

a[halide $] /[$ boronic acid $] /\left[\mathrm{K}_{3} \mathrm{PO}_{4}\right]=1 / 1.15 / 5.0 ;[\mathrm{Pd}] /[\mathrm{R}-\mathrm{X}]=1: 200 ; 383 \mathrm{~K} ; 2 \mathrm{~h}$; toluene. 
Table 5. Suzuki coupling reactions with $p$-chlorophenylboronic acid catalyzed by $\mathbf{1 c P d}_{\mathbf{3}}(\mathbf{d b a})$ in low loadings ${ }^{\mathrm{a}}$

\begin{tabular}{|c|c|c|c|c|}
\hline entry & base & $\mathrm{R}-\mathrm{X}$ & yield / \% & TON \\
\hline 1 & $\mathrm{KF}$ & & 62 & 17,100 \\
\hline 2 & $\mathrm{~K}_{3} \mathrm{PO}_{4}$ & & $\begin{array}{c}63.5 \\
(56.5)^{2}\end{array}$ & $\begin{array}{c}17,500 \\
(15,600)^{\mathrm{b}}\end{array}$ \\
\hline 3 & $\mathrm{KF}$ & & 57.9 & 16,000 \\
\hline 4 & $\mathrm{~K}_{3} \mathrm{PO}_{4}$ & & 53.5 & 14,800 \\
\hline
\end{tabular}

${ }^{\mathrm{a}}[\mathrm{RX}] /[\mathrm{Pd}]$ ca. 28,000; $383 \mathrm{~K}$. b Using a catalyst solution five days after preparation.

coupling of 2-bromotoluene with 4-chlorophenylboronic acid using a freshly catalyst solution. The same catalyst solution, kept on the bench for five days, allowed a TON of 15,600 , evidencing the robustness of this system. Interestingly, the results were better for the hindered 2-bromotoluene than for 3-bromotoluene.

The higher activity of $\mathbf{1} \mathbf{c P d}(\mathbf{d b a})$ (when compared with $\mathbf{1} \mathbf{a P d} \mathbf{P}_{\mathbf{3}}(\mathbf{d b a})$ and $\left.\mathbf{1 b P d}_{\mathbf{3}}(\mathbf{d b a})_{3}\right)$ was expected as a consequence of the higher eletron-donor ability and steric demand of the $\mathrm{P}(\mathrm{Cy})_{2}$ groups. The results obtained with $\mathbf{1 c P d}_{\mathbf{3}}(\mathbf{d b a})$ at $353 \mathrm{~K}$ compare well with those reported for $\mathrm{Pd} / \mathrm{P}\left({ }^{(} \mathrm{Bu}\right)_{3}$ at room temperature in optimized conditions. ${ }^{1}$ The cyclophosphazene backbone might account for the need of higher temperatures as it would be more difficult to reach a palladium-monophosphine species, believed to start the catalytic cycle, ${ }^{1,3,16}$ as a non coordinated phosphine would always be nearby. For the same reason, it could also account for the stability of solutions containing $\mathbf{1} \mathbf{c P d}(\mathbf{d b a})$, which could be kept on the bench for several days without decomposition. It should be noted that, although the reactions were carried out under argon, the complexes were stored under air, at room temperature, and were stable in such conditions for at least four months.

\section{Attempts to catalyst immobilization}

The good results obtained in the catalytic tests encouraged further experiments aiming to the immobilization of the catalyst. Therefore, $\mathbf{1 a P d}_{\mathbf{3}}(\mathbf{d b a})$ was encapsulated in a silica matrix prepared by the sol-gel method following a procedure developed in our laboratory. ${ }^{11}$ Although less active than $\mathbf{1 c P d}_{\mathbf{3}}(\mathbf{d d b a}$, $\mathbf{1 a P d}_{3}(\mathbf{d b a})$ was expected to be less sensitive to the experimental conditions involved in the gel preparation. Owing to the very low catalyst loading (although several attempts were done aiming to entrap higher amounts of catalyst, we failed to reach more than $0.06 \mathrm{wt} . \% \mathrm{Pd}$ ), no spectroscopic characterization could be performed. The nitrogen adsorption-desorption isotherms characterized a microporous system (average pore diameter: $20 \AA$; pore volume: $\left.0.37 \mathrm{~cm}^{3} \mathrm{~g}^{-1}\right)$ with a high surface area $\left(729 \mathrm{~m}^{2} \mathrm{~g}^{-1}\right)$. The encapsulated catalyst was tested in the coupling of bromobenzene with phenylboronic acid $(\operatorname{method} \mathrm{A})$ and could be used in at least 3 runs without losses in catalytic activity (TON $c a .93$ in each run). A TON slightly lower than that obtained in solution in the same experimental conditions (method A) might be ascribed to diffusion problems intrinsic to a porous material. ${ }^{11}$

In spite of the microporous character of the matrix, some leaching was observed after each reaction as the solution became yellowish. Nevertheless, as the yields in each run were kept constant (within the experimental error), it can be assumed that catalysis was performed mainly by the immobilized complex. In order to avoid leaching of the complex, a ligand similar to 1a but bearing a hydrolysable group, 1a', was prepared according to Scheme 2. Since Pd bound to a cross-linked polymer derived from this kind of ligand (when the hydrolysable group is replaced by a vinyl one) proved to be an efficient and recyclable catalyst for Heck reactions of aryl iodides, ${ }^{9}$ we expected that a silica supported analogue could be viable for Suzuki reactions.

Therefore, ligand 1a' was complexed with palladium (ca. 3 equiv., in order to ensure that all phosphine groups would be involved in coordination with palladium) and allowed to react with silica gel. The whole preparation was rather tedious and only a small amount of catalyst was produced. Nevertheless, the amount of immobilized palladium was twice that obtained in the case of encapsulated $\mathbf{1} \mathbf{a P d} \mathbf{P d}_{3}(\mathbf{d b a})$.

The ${ }^{31} \mathrm{P}$ MAS NMR spectrum of the anchored complex showed a signal in $\delta 22$, assigned to $-\mathrm{PPh}_{2}$ coordinated to Pd. The mesoporous character of the silica matrix was maintained (average pore diameter: $103 \AA$; pore volume: $0.44 \mathrm{~cm}^{3} \mathrm{~g}^{-1}$; surface area: $154 \mathrm{~m}^{2} \mathrm{~g}^{-1}$ ). Preliminary catalytic experiments with this system in the coupling of bromobenzene with phenylboronic acid showed a lower yield (TON ca. 49, method A) than those obtained by its homogeneous and encapsulated analogues, but no leaching could be detected. Owing to the small amount of available catalyst, only a few qualitative recycling experiments could be performed, with the catalyst showing no visible changes. Although the proposed immobilization route seems to be too much cumbersome for practical purposes, the stability of the resulting catalyst may encourage further studies with substituted cyclophosphazenes as pendant ligands for palladium complexes. 
<smiles>ClP1(Cl)=NP(Cl)(Cl)=NP(Cl)(Cl)=N1</smiles>

i) 4'-methoxybiphenyl-4-ol $\mathrm{Et}_{3} \mathrm{~N}$, benzene, $6 \mathrm{~h}$

ii) $\mathrm{Cs}_{2} \mathrm{CO}_{3}$, acetone reflux, $2 \mathrm{~h}$

(4-hydroxyphenyl)diphenyl-phosphine<smiles>Oc1ccc(P)cc1</smiles><smiles>COc1ccc(-c2ccc(OP(=N)(N)Oc3ccc(-c4ccccc4)cc3)cc2)cc1</smiles><smiles>c1ccccc1</smiles><smiles>c1ccc(-c2ccccc2)cc1</smiles><smiles>[CH]=N</smiles>

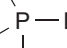

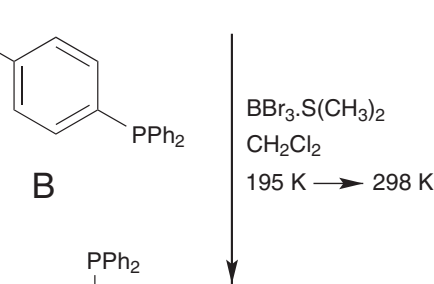<smiles>CCO[Si](CCCOc1ccc(-c2ccc(OP3(Oc4ccc(Pc5ccccc5)cc4)=NP(Oc4ccc(P)cc4)(Oc4ccc(P)cc4)=NP(O)(OC)=N3)cc2)cc1)(OCC)OCC</smiles><smiles>C[PH]1=NP(Oc2ccc(P)cc2)(Oc2ccc(P)cc2)=NP(Oc2ccc(F)cc2)(Oc2ccc(-c3ccc(O)cc3)cc2)=N1</smiles>
$\mathrm{Ph}_{2} \mathrm{P}$<smiles>OP(P)Oc1ccc(P)cc1</smiles>
$-\mathrm{N}$<smiles>Cc1ccc(P)cc1</smiles>

C

Scheme 2. Schematic preparation of ligand 1a'.

\section{Conclusions}

The syntheses of three novel palladium complexes obtained by reaction of phosphine-linked cyclophosphazenes, $\left(\mathrm{P}_{3} \mathrm{~N}_{3}\right)\left(\mathrm{O}-\mathrm{C}_{6} \mathrm{H}_{4}-\mathrm{PR}_{2}\right)_{6}$, where $\mathrm{R}=$ phenyl, 1a, $i$-propyl, $\mathbf{1 b}$, or cyclohexyl, 1c, with $\mathrm{Pd}_{2}(\mathrm{dba})_{3}$ were reported. All complexes were active in Suzuki coupling reactions of arylbromides, with the cyclohexylphosphine derivative, $\mathbf{1 c P d}_{3}(\mathbf{d b a})$, being active towards arylchlorides. This complex proved to be robust (could be kept in solution, at room temperature, for at least one week) and could be used in low loadings, affording turnover numbers as high as $c a$. 17,500 for the coupling of 2-bromotoluene with chlorophenylboronic acid. Entrapment of complex $\mathbf{1 a P d}_{\mathbf{3}}(\mathbf{d b a})$ by the sol-gel method provided a recyclable catalyst, in spite of some leaching. Although the use of a modified ligand, bearing a hydrolysable group, allowed the preparation of a silicaanchored leaching-proof catalyst, the procedure appeared not to be adequate for practical purposes.

\section{Supplementary Information}

Supplementary information ( ${ }^{31} \mathrm{P}$ NMR, FT-IR and mass spectra of all new compounds; gas phase chromatograms of selected reactions with identification of products) is available free of charge at http://jbcs.sbq.org.br as pdf file.

\section{Acknowledgments}

Financial support from FAPESP and CNPq is gratefully acknowledged.

\section{References}

1. Fu, G. C.; Acc. Chem. Res. 2008, 41, 1555.

2. Tobisu, M.; Chatani, N.; Angew. Chem., Int. Ed. 2009, 48, 3565.

3. Martin, R.; Buchwald, S. L.; Acc. Chem. Res. 2008, 41, 1461.

4. Kantchev, E. A. B.; O'Brien, C. J.; Organ, M. G.; Angew. Chem., Int. Ed. 2007, 46, 2768.

5. Adidou, O.; Goux-Henry, C.; Safi, M.; Soufiaoui, M.; Framery, E.; Tetrahedron Lett. 2008, 49, 7217.

6. Wu, X.-F.; Neumann, H.; Beller, M.; Tetrahedron Lett. 2010 , $51,6146$.

7. Chandrasekhar, V.; Thilagar, P.; Pandian, B. M.; Coord. Chem. Rev. 2007, 251, 1045. 
8. Allcock, H. R.; Lavin, K. D.; Tollefson, N. M.; Evans, T. L.; Organometallics 1983, 2, 267.

9. Chandrasekhar, V.; Athimoolam, A.; Org. Lett. 2002, 4, 2113.

10. Teixeira, S.; Dallmann, K.; Schuchardt, U.; Buffon, R.; J. Mol. Catal. A: Chem. 2002, 182-183, 167.

11. Campos, J. D. R.; Buffon, R.; New J. Chem. 2003, 27, 446.

12. Pellegrino, R. B.; Buffon, R.; J. Braz. Chem. Soc. 2004, 15, 527.

13. Carriedo, G. A.; Alonso, F. J. G.; González, P. A.; Gómez-Elipe, P.; Polyhedron 1999, 18, 2853.
14. Mann, B. E.; Musco, A.; J. Chem. Soc., Dalton Trans. $\mathbf{1 9 7 5}, 1673$.

15. Hills, H. D.; Fu, G. C.; J. Am. Chem. Soc. 2004, 126, 13178.

16. Christmann, U.; Vilar, R.; Angew. Chem., Int. Ed. 2005, 44, 366.

Submitted: June 29, 2011

Published online: November 29, 2011

FAPESP has sponsored the publication of this article. 